\title{
LAN-Based Vehicle Information System for Motor Vehicle Registration Office
}

\author{
VANESSA MAE E. VALENCIA, JUDE ISRAEL REGOJOS, \\ JET RENZ FERRER, and FROILAN D. MOBO*
}

AMA Computer College, Olongapo City, Philippines.

\begin{abstract}
The proponents of this study proposed the idea of making a LAN-Based Vehicle Information System to improve the conventional method of record administration for Engine Vehicle Enlistment Office. The illustrative strategy for inquire about was connected to the investigation. Research and meetings were led to fortify the assumption of issues and hidden issues on various zones of the ebb and flow data framework were found in light of the respondent's answers. The LAN-Based Vehicle Data framework won't just evaluate yet will likewise lighten the issue and tedious procedure of the old framework. Also, the proposed framework would yield ongoing procedures and more advantageous. The goal of this examination is to have a data framework that is more proficient and bother free in record administration. The investigation presents advancement of data frameworks from the conventional to the top of the line innovation. Uncovering the mechanics of the said framework and displaying information upheld points of interest that can be picked up utilizing LAN-Based Data Framework. Sorted out interface and usefulness gives speed and productivity, end of problem and lessen of time. The MVRO (Motor Vehicle Registration Office) is a department that is in charge of regulating the transportation in Subic Bay Freeport Zone. It systematizes the transportation inside the SBFZ and has 275 registered taxis aside to 500 registered shuttle buses, public utility vehicles and company vehicles. According to the Officer-In-Charge of MVRO, Mrs. Marietta Fe S. Dumlao, their database only reside to excel and not organized to the various categories of the registered vehicles .
\end{abstract}

\section{Introduction}

Information systems are developed for the improvement of the necessities of a company and to provide solutions to their problems in data processing, data presentation, and record-keeping. It supports decision-making activities and statement of

CONTACT Dr. Froilan D. Mobo froilanmobo@gmail.com 9 AMA Computer College, Olongapo City, Philippines. (C) 2018 The Author(s). Published by Oriental Scientific Publishing Company

This is an 6 Open Access article licensed under a Creative Commons Attribution-NonCommercial-ShareAlike 4.0 International License (https://creativecommons.org/licenses/by-nc-sa/4.0/), which permits unrestricted NonCommercial use, distribution, and reproduction in any medium, provided the original work is properly cited.

To link to this article: http://dx.doi.org/10.13005/ojcst11.01.04 
the progress of an organization. It produces reliable output by keeping track of records with minimum data redundancy, reduction of paper works, improved data quality, accessibility and responsiveness, and elimination of human errors, which is the main purpose of using information systems. Because of these advantages, the use of information systems will be beneficial to different institutions especially universities and government agencies $4,5,6,7,8,9,10,11$.

Subic Bay Metropolitan Authority is a government agency that has a big role on uprising of Subic Bay Freeport Zone in Zambales. It has different departments but one of the departments that have a role of regulating the transportation inside the SBMA is the MVRO. Motor Vehicle Registration Office is the one who regulates and administrate the motors and vehicles that are running around the SBMA. The operator of the said vehicle needs to register on the MVRO to run his vehicle inside the community by accomplishing the needed requirements. After an interview to the MVRO Office-in-Charge, the following situations were noted by the researcher: (1) Difficulty in searching for individual records, (2) Monitoring of expired registration is sometimes being missed, (3) Generating of detailed reports cannot be easily done. These problems were caused mainly by the old record - keeping and transaction system.

The main objective of the proposed system is to provide an information system for managing their records. The system will be networked that will allow the sharing of data from each of the workstations. It will be easier compared to those who use independent workstations because it is more convenient and the processes will be faster and real-time ${ }^{1,2,3}$.

\section{Statement of The Problem General Problem}

The MVRO (Motor Vehicle Registration Office) is a department that is in charge of regulating the transportation in Subic Bay Freeport Zone. It systematizes the transportation inside the SBFZ and has 275 registered taxis aside to 500 registered shuttle buses, public utility vehicles and company vehicles. According to the Officer-In-Charge of MVRO, Mrs. Marietta Fe S. Dumlao, their database only reside to excel and not organized to the various categories of the registered vehicles.
Their PC is also a stand-alone that only one staff is able to access the data. And because of the huge number of the registered vehicles, the biggest challenge to their department is generating detailed reports of the driver's information.

\section{Specific Problem}

- $\quad$ Difficulty in searching for individual records.

- Monitoring of expired registration is sometimes being missed.

- Generating of detailed reports cannot be easily done.

- Lack of security in terms of accessing the confidential files.

\section{Materials and Methods}

\section{System Development Model}

In helping the proponents achieve the desired proposed system, research tools and techniques are used. Activities were done to utilize the information that the proponents obtained.

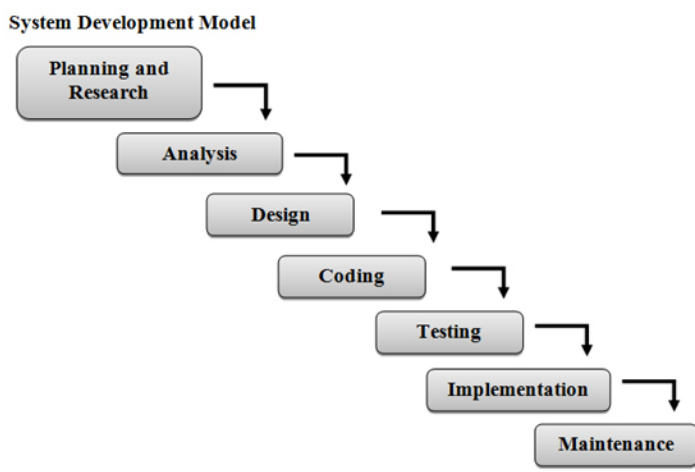

Fig. 1: System Development Model Waterfall Model

The following discuss the phases involved in the model:

\section{Planning and Research}

The design gives the advocates the chance to talk about the proposed framework, expressing its significance and how it will be led. This stage is centered around the goal of the examination and social affair of data for investigation.

\section{Investigation}

The goal of this stage is principally to assemble the product prerequisites determination and make an 
outline in light of the necessities. The advocates assembled data through meeting, web and library examine. After assembling every one of the information, the advocates directed workshops and conceptualizing where they thought of a functional outline stories and a framework that is as indicated by the clients' needs.

\section{Outline}

In the wake of coding, the scientists figure out how to outline the screen format, what will be the look of the UI and what will be the shading plan to be utilized. Catch connections and pictures are arranged and done in this stage.

\section{Coding}

Amid this stage, the defenders built up the framework utilizing PhP and MySQL. The defender code and after that test until the point that the advancement is refined.

\section{Testing}

Amid this stage the advocates tried the framework. After the planning and encoding all the required capacities, the advocates checked and tried the usefulness of the framework

\section{Usage}

This stage would concentrate on execution of the data framework. The improvement group would set up the exchanges and movement of the framework to the clients' PC. The proposed framework was transferred for additionally testing and starting execution.

\section{Support}

Once the recipient begins utilizing the created framework it ought to dependably be refreshed and keep educated to the capacities displayed. Support is basic to keep premises and the workplace protected and dependable. It is critical that an arranged support software engineer is set up and that all upkeep work is hazard surveyed before starting the assignment.

\section{Research Instruments}

The respondents utilized various types of instrument to make this investigation conceivable. The accompanying apparatuses were utilized for social event of information:

\section{Meeting}

The Group directed a meeting with Mrs. Marietta Fe Dumlao, the Officer Responsible for MVRO, to accumulate all the data required for the advancement of the proposed framework. The advocates masterminded a meeting guide which plans to secure information, for example, the driver's necessity for enrollment and infringement procurement.

\section{Web Research}

The group utilized the web in social occasion steady and related actualities and most recent data related with the proposed framework to further understanding. This device was utilized to get important data concerning the examination.

\section{Library Research}

The advocates utilized the library for extra assembling data. Library contributed a great deal in giving data particularly as far as related writing that have been useful in giving related articles.

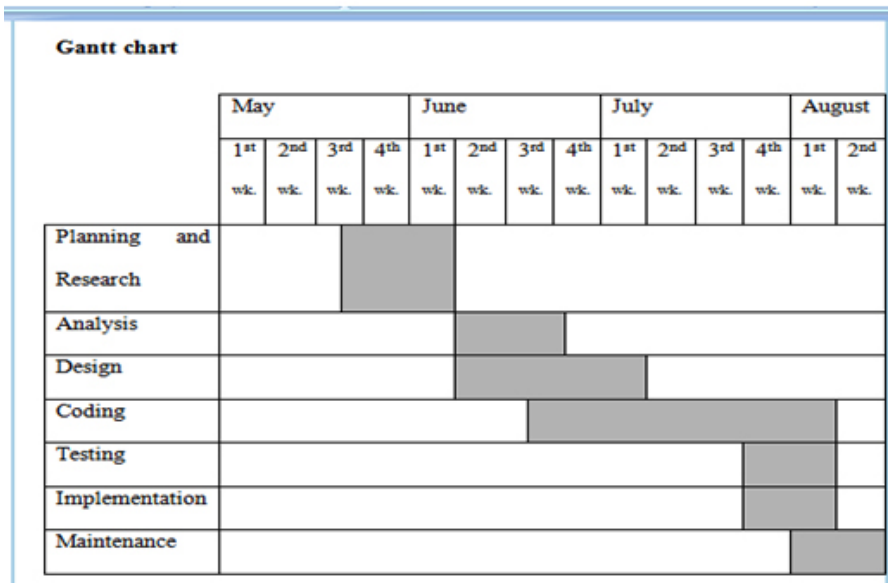

Fig. 2: Shows the progress made by the proponents during the development of the system 


\section{Flowchart}

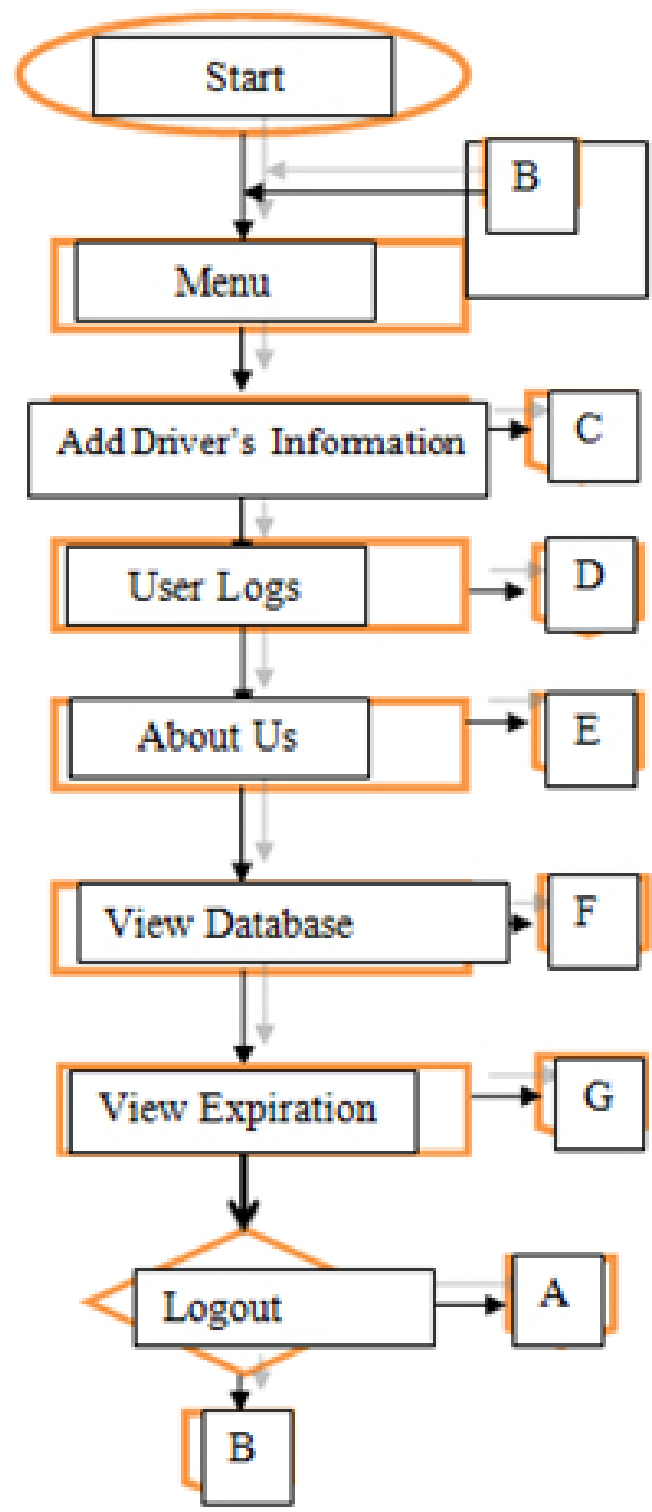

Fig. 3: Admin System Dashboard. This show the System's Overview where you can see the management categories of the system

\section{Results and Discussions}

Table 1 shows the tangible requirements for the propsed system. It shows the hardware components used in developing the propsed system. The researchers used RAM with 4GB, A microprocessor with at least $2 \mathrm{GHz}$, and a mouse and keyboard.
Table 1: Hardware Development Components

\begin{tabular}{|c|c|c|}
\hline $\begin{array}{l}\text { Hardware } \\
\text { Name }\end{array}$ & Specification & Description \\
\hline $\begin{array}{l}\text { RAM(Random } \\
\text { Access Memory) }\end{array}$ & $\begin{array}{l}\text { At least } 4 G B \\
\text { of RAM }\end{array}$ & $\begin{array}{l}\text { The part of a computer } \\
\text { in which information is } \\
\text { stored temporally } \\
\text { when a program is } \\
\text { being used. }\end{array}$ \\
\hline $\begin{array}{l}\text { Mouse and } \\
\text { Keyboard }\end{array}$ & $\begin{array}{l}\text { Generic mouse } \\
\text { and keyboard }\end{array}$ & $\begin{array}{l}\text { Input devices used } \\
\text { in a computer. }\end{array}$ \\
\hline Microprocessor & At least $2 \mathrm{GHz}$ & $\begin{array}{l}\text { The device in a } \\
\text { computer that manage } \\
\text { information and control } \\
\text { what the computers } \\
\text { does. }\end{array}$ \\
\hline
\end{tabular}

Table 2 shows the software development Components used in developing propsed system. The researchers used Visula Basic as their source code editor since they got background coding on this platform and easy to understand. XAMPP Web Server was used to crate a local web server. Adobe photoshop was used for the porpose of creating a banner of the system.

Table 2: Software Development Components

\begin{tabular}{|c|c|c|}
\hline $\begin{array}{l}\text { Software } \\
\text { Name }\end{array}$ & $\begin{array}{l}\text { Developer } \\
\text { /Manufacturer }\end{array}$ & Description \\
\hline $\begin{array}{l}\text { Microsoft } \\
\text { Windows } 10 \\
\text { XAMPP Web } \\
\text { Server }\end{array}$ & $\begin{array}{l}\text { Microsoft Corp. } \\
\text { Apache Friends }\end{array}$ & $\begin{array}{l}\text { A personnel computer } \\
\text { operating system. } \\
\text { A free and open source } \\
\text { cross-platform web server } \\
\text { solution stack Package. }\end{array}$ \\
\hline MySQL & $\begin{array}{l}\text { Database } \\
\text { Applications }\end{array}$ & $\begin{array}{l}\text { A database server that } \\
\text { provides scalable data } \\
\text { storage/retrieval. }\end{array}$ \\
\hline $\begin{array}{l}\text { Adobe } \\
\text { Photoshop }\end{array}$ & Adobe Systems & $\begin{array}{l}\text { Adobe Photoshop is the. } \\
\text { most popular photo } \\
\text { editing software that } \\
\text { allows you to enhance } \\
\text { photesn }\end{array}$ \\
\hline Visual Basic & Alan Cooper & $\begin{array}{l}\text { A third-generation event } \\
\text {-driven and a user } \\
\text { friendly programming } \\
\text { language designed for } \\
\text { beginners. }\end{array}$ \\
\hline
\end{tabular}


This chapter concludes the study. The conclusion and recommendations included in this chapter discusses the summarization of all the benefits, features and significance of the proposed system to the beneficiaries.

\section{Conclusion}

In the implementation of the proposed system, the beneficiary will have a system with greater accuracy in record management and will save time for them. It will resolve the currently identified problems of the business which includes difficulty in searching for individual records, processes takes time, generating of detailed reports cannot be easily done and lack of security in terms of accessing the confidential files. The proposed system provide an information system for managing their records. The system will also be networked that will allow the sharing of data from each of the workstations. It will be easier compared to those who use independent workstations because it is more convenient and the processes will be faster and real-time. The proponent therefore conclude that implementation of the proposed system will benefit the business a lot more than it cost.

\section{Recommendations}

The Information System of Motor Vehicle Registration Office is expected to be fully functional upon implementation. The proponents recommend the agency to obtain the appropriate hardware and software requirements for the system to operate fully as expected. End-user training should not be of the strenuous since the system is designed to be very user friendly. However, prompt orientation to all users and involved personnel should not be ignored but even considered to be great significance in order to meet the optimum desired benefits that the system may provide.

Transition from the existing to the proposed system would not give much hassle if properly used and implemented. In its implementation phase, as soon as there may be any innovation, the system should be updated to be aligned with the change introduce.

\section{Acknowledgement}

First of all, the researchers, would like to offer their sincerest gratitude to God Almighty for continuously giving them strength and wisdom while doing this software engineering project; for unconditional love and for continuously showering them blessings along the way.

The researchers would also like to thank their research adviser, Dr. Froilan Mobo, who supported them to what they are now.

The researchers would like to express their gratitude to their families and friends who encouraged and motivated them that brings the project to success. Especially, the financial support the families gave.

Lastly, they would like to show appreciation to their beloved college, the AMA Computer CollegeOlongapo Campus for giving them the opportunity to make this project possible.

\section{References}

Al-Saedi(2015)"Implementation of LANBased IP Telephony Simulator" retrieved from https://www.researchgate.net/ publication/299443909_Implementation_of_ LAN-Based_IP_Telephony_Simulator.

2 Almadani(2014)"Automatic Vehicle Location and Monitoring System Based on Data Distribution Service" Retrieved from http:// www.sciencedirect.com/science/article/pii/ S1877050914009867.

3 Bavais(2015)"PC-Based Electronic Bulletin Board" retrieved from http://Ipulaguna. edu.ph/wp-content/uploads/2016/08/3.
DEVELOPMENT-OF-A-PC-BASEDELECTRONIC-BULLETIN-BOARD.pdf.

4 Gunawan(2015)"LAN-Based Application of File Management in the Computer Laboratory of School of Applied Science" Retrieved from https://www.researchgate. net/publication/298700404_Lan-based_ application_of_file_management_in_the computer_laboratory_of_school_of_applied_ science.

Lee (2012)" LAN-Based Inventory System"retrieved from https://prezi.com/ jknp-re_r9qi/lan-based-inventory-system/ 
Padua(2015)"LAN-Based ISO Database Management System of Quality Management and Planning Department in LetranCalamba" retrieved from https://ejournals.ph/article. php?id=10912.

Platilla(2016)"LAN-Based Expidenture Monitoring System of Sta. Cruz, Laguna"Retrieved from https://ejournals.ph/ article php?id=10848.

8 Reyes(2015)"LAN-Based Information System for College of Information and Communications Technology" Retrieved fromhttp://www.ijias. issr-journals.org/abstract.php?article=IJIAS15-111-03.
9 Selvaraj(2017)"Smart Dustbin Monitoring System using LAN-Server and Arduino" retrieved from https://www.researchgate. net/publication/315725507_Smart_Dustbin_ Monitoring_System_using_LAN_Server_ and_Arduino.

10 Vehicle Registration System. (2016). Retrieved from http://www.smartcube. co/INDUSTRIES/TransportationTraffic/ VehicleRegistrationSystem.aspx.

11 Vehicle license registration system. (2016, November 1). Retrieved from https://www. slideshare.net/AgbonaAzeez/vehicle-licenseregistration-system. 